\title{
Üniversite Öğrencilerinin Gelecekleriyle İlgili Kaygı ve Beklentilerinin Belirlenmesi
}

\author{
Burhanettin ZENGIN*, Ümit ŞENGEL**
}

ÖZ

Dünyada yaşanan önemli değişimlerin meydana getirdiği belirsizlikler başta genç nüfus olmak üzere çoğu insanın geleceğe yönelik kaygı ve beklenti düzeylerini etkileyebilmektedir. Bu bağlamda araştırmada Türkiye'de turizm eğitimi alan öğrencilerin kayg1 ve beklenti düzeylerinin belirlenmesi ve kaygı ve beklenti düzeylerini etkileyen faktörlerin ortaya konması amaçlanmaktadır. Araştırmada nicel araştırma yöntemlerinden yararlanılmış ve veri toplama aracı olarak anket tekniği kullanmıştır. Türkiye'de kamu ve vakıf üniversitelerinde öğrenim gören toplam 2.578 öğrenciden veriler elde edilmiştir. Çalışmanın sonuçlarına göre üç beklenti, bir kaygı boyutu oluşmuştur. Bu boyutlar öğrencilerin bazı betimleyici değişkenlerine göre anlamlı farklılıklar göstermiştir. Aile yapısı, terör ve eğitimin niteliği Türkiye'deki üniversite öğrencilerinin kaygı ve beklenti düzeylerini etkileyen en önemli üç faktördür. Bununla birlikte, öğrencilerin kaygı ve beklentileri arasında anlamlı bir korelasyon da tespit dilmiştir.

Anahtar Kelimeler: Kaygı, Beklenti, Üniversite Öğrencisi, Türkiye

JEL Sinıflandırması: L83, Z39

\section{Determination of the Anxiety and Expectations of University Students about Their Future}

\begin{abstract}
Uncertainties caused by significant changes in the world can affect the anxiety and expectation levels of most people, especially for young people. In this context, it is aimed to determination of anxiety and expectation of tourism education students and the factors that affect them in Turkey. Quantitative research methods were used in the research and survey technique was used as a data collection tool. The data was obtained from total of 2,578 students, who are studying at public and private universities in Turkey. According to the results of the study, three expectations and one anxiety dimension were formed. These dimensions differed significantly according to some descriptive variables of the students. Family structure, terrorism, and the quality of education were the three most important factors affecting university students' anxiety levels and expectations in Turkey. In addition, a significant correlation was found between the anxiety and expectations of the students.
\end{abstract}

Keywords: Anxiety, Expectation, University Student, Turkey

JEL Classification: L83, Z39

Geliş Tarihi / Received: 04.02.2020 Kabul Tarihi / Accepted: 15.04.2020

\footnotetext{
* Prof. Dr., Sakarya Uygulamalı Bilimler Üniversitesi, Turizm Fakültesi, Turizm Rehberliği Bölümü, bzengin@ sakarya.edu.tr, ORCID: 0000-0002-6368-0969.

** Araş. Gör. Dr., Sakarya Uygulamalı Bilimler Üniversitesi, Turizm Fakültesi, Turizm Rehberliği Bölümü, umitsengel@gmail.com, ORCID: 0000-0003-1284-836X.
} 


\section{GİRIŞ}

20 yy'in ikinci yarısında dünyada öğrencilerin kaygı ve beklentilerini etkileyen bazı önemli gelişmeler (krizler) meydana gelmiştir. Özellikle dünyanın çeşitli bölgeleri 1990’lı yılların başından beri birçok ekonomik krizi yaşamıştır. Örneğin, 1991 yılında Avrupa Döviz Kuru Mekanizması krizi, 1994-95 yıllarında Latin Amerika'da tekila krizi, 1997'de Asya krizi, 1998'de Rusya krizi, 2000 ve 2001'de Türkiye'de bankacılık krizleri ve 2008 yılında önce Amerika Birleşik Devletleri'nde ortaya çıkan ve sonra tüm gelişmiş ve gelişmekte olan ülkeleri etkisi altına alan bir finansal kriz yaşanmıştır. Çok sayıda araştırmacı, reel ekonomi üzerinde çok ciddi etkileri olan bu krizlerin sebeplerini ve belirtilerini ortaya çıkarmak ve öncesinden tahmin edecek sistemler geliştirmek için çaba sarf etmektedir. Politik, ekonomik, sosyolojik ve siyasal kaynaklı olabilen bu krizlerin toplumları birçok açıdan olumsuz yönde etkilediği bir gerçektir. Krizlere duyarlı sektör veya endüstriler bu olumsuzluklardan en çok etkilenen alanlar olmaktadir.

Krizlere duyarlı endüstrilerin başında da turizm endüstrisi gelmektedir. Turizm endüstrisinin seyahat olgusu içermesi ve katılanlar için belli miktarda ekonomik güç gerektirmesi gibi nedenlerle bu krizlerden genellikle olumsuz etkileneceği ifade edilmektedir. Turizm; ekonomik kriz, savaş, terör, ülkeler arasındaki siyasi ve politik gerilimler, vize sorunları gibi birçok duruma karşı duyarlıdır (Hall ve O’Sulivan, 1996; Pearson ve Clair, 1998; Clements ve Georgiou, 1998; Anderson, 2006; Hallgren ve Wilson, 2008; Firat ve Açıkgöz, 2011; Fielding ve Shortland, 2011; Öztürk ve Şimşek, 2013).

Turizm endüstrisinin krizlerden çabuk etkilenen hassas yapısı, bu endüstrilerle bağlantılı birçok alt sektörü de etkilemektedir. Özellikle üniversitelerde turizm eğitimi gören öğrenciler, turizmin krizlere karşı olan duyarlı yapısı nedeniyle, turizm ve turizm eğitimine karşı olumsuz tutum sergileyebilmektedirler. Çünkü gelecekte işveren/işgören olarak yer alabilecekleri endüstri bu bağlamda kendilerine yeterince güven vermemektedir. Bir ülke, bölge veya dünya ölçeğinde gerçekleşen veya gerçekleşme ihtimali yüksek olan krizler, ülkelerin sosyo-kültürel, ekonomik, coğrafik veya siyasi yapılarını, turizm endüstrisini ve turizm ile ilgili eğitim alan gençlerin kaygı ve beklenti düzeylerini olumsuz yönde etkileyebilmektedir. Turizm öğrencilerinin gelecekle ilgili beklentilerinden söz edildiğinde, genellikle turizmle ilgili alt sektörlerdeki işlerden kaynaklı bir kaygı veya beklentinin varlığından söz edilir. Ancak bunun dışında krizler ve toplumsal yapıdan kaynaklı kaygı ve beklentilerden söz etmek de gerekir ki, bu alanda England ve diğerleri (2017) belirttiği gibi öğrencilerin kaygı ve beklentileri ile ilgili literatürde benzer çalışmalar bulunmaktadır.

Bir ülkenin geleceğe ilişkin en önemli dinamiklerinden biri de ülkede bulunan genç nüfustur. Dolayısıyla gençlerin geleceğe ilişkin kaygı veya beklentilerinin bilinmesi, onlara daha iyi bir gelecek hazırlama veya onların daha iyi bir geleciği inşa etmede aracı rol üstlenmeleri gibi durumları beraberinde getirebilmektedir. Özellikle üniversite düzeyindeki gençleri gelecekleriyle ilgili bir planlama yapmalarının yolu kaygı ve beklentilerinden geçmektedir. Böyle bir süreçte yapılan bu çalışmanın hem makro anlamda ülkeye hem de mikro anlamda gençlere yol gösterici bir role sahip olduğu düşünülmektedir.

\section{LITERATÜR TARAMASI}

Bir toplumun mutluluğu bireylerinin mutluluğundan başlar. Bu anlamda ülkelerin temel amaçlarında biri de, vatandaşlarının mutlu ve umutlu olmalarına zemin hazırlayacak uygulamaları gerçekleştirmektir. Bireylerin mutlu olmalarının pek çok sebebi olabilir. Tutar (2007) bireylerin mutluluğu için umutlarının fazla, kaygılarının düşük olması gerektiğini vurgulamaktadır. Mutlu olmanın önemli yollarından biri de insanların geleceğe yönelik kurguladıkları beklentilerinin gerçekleşmesinden geçmektedir. $\mathrm{Bu}$ nedenle mutlu toplum, 
geleceğe yönelik kaygı düzeyleri düşük ve olumlu beklentileri gerçekleşmiş bireylerden oluşan toplum olduğu söylenebilir.

Uluçay ve arkadaşları (2014: 235) gençlerin beklentilerini belirleyen bazı önemli değişkenlerin olduğunu vurgulamaktadır. Özellikle cinsiyet, değerler, kültür, aile yapısı ve ailenin yaşam koşulları ve çevre gibi unsurlar bunlardan bazılarıdır. Bu değişkenlerden bazıları bu çalışma kapsamında da ele alınmış ve bunların gençlerin kaygı ve beklentilerini belirleyen bazı rolleri tespit edilmiştir.

Güleri (1998) ifade ettiği gibi kaygı ve beklenti toplumsal hayatın içinde sürekli var olan iki kavramdır. Bir toplumun gelişim çizgisini ve gelecekle ilgili dinamizminin en temel belirleyicilerinden biri de genç nüfusunun beklentileridir. Sanayi ve/veya bilgi toplumlarında ekonomik yaşamın içerisinde bireylerin rekabet edebilme ve başarılı olmalarının çocukluk yaşlarında başlayan gelecek kaygı ve beklentileri ile de şekillendiği ifade edilebilir. Bunlar nitelikli insan olmak isteyen bireylerin bütün hayatları boyunca sürüp giden çabalarıdır. $\mathrm{Bu}$ durum sanayi ve/veya bilgi toplumlarının genel olarak bir isteğidir.

Dünyada turizm öğrencilerinden önce, daha genel ve bütün alanlarda okuyan öğrencilerin kaygı ve beklentilerine yönelik çalışmalar yer vermekte yarar vardır. Bu kaygı ve beklentileri için ise, genellikle makro çevresel sebeplerin üzerine odaklanılmaktadır. $\mathrm{Bu}$ çalışmalar genellikle lise, ön lisans, lisans öğrencileri ile ilgili olmakla birlikte lisansüstü öğrencilerinin kayg1 ve beklentilerine yönelik çalışmalarda mevcuttur (Zaaba, vd., 2014; Fitzpatric, vd., 2016; Saiti vd., 2017). Örneğin, Üngüren ve Ehtiyar (2009) Türkiye ve Almanya'daki öğrencilerin umutsuzluk (kaygı) düzeylerine yönelik yaptıkları çalışmada her iki ülkeden katılımcıların umutsuzluk (kayg1) düzeylerinin eğitim memnuniyeti tarafından etkilendiğini tespit etmişlerdir. Buna ek olarak, Türkiye'deki öğrencilerin kaygılarını okul başarısı, arkadaş ilişkileri, cinsiyet ve gelir gibi değişkenleri de etkileyebilmektedir. Uluçay ve arkadaşlarının (2014) lise öğrencilerin beklentilerine yönelik yaptıkları çalışmada, öğrencilerin eğitim gördükleri okul türleri beklentilerini etkileyen bir faktör olarak tespit edilmiştir. Türkiye'de Erzincan ilinde yapılan bu çalışmada en yüksek beklentiye sahip okul türü spor liseleri olurken, en düşük beklentiye sahip lise türü ise müzik liseleri olmuştur. 12 lise türünün yer aldığı araştırmada turizm ve otelcilik liseleri en yüksek beklentiye sahip öğrenci grupları sıralamasında dokuzuncu olabilmiştir.

England ve diğerleri (2017) Amerika'da aktif öğrenmenin öğrencilerde kaygıya sebep olup olmadığıyla ilgili biyoloji eğitimi alan öğrenciler üzerine yaptıkları çalışmada, aktif öğrenmenin öğrencilerin kaygılarını etkilediğini tespit etmişleridir. Online anket yoluyla 327 katılımcıdan veri toplayan araştırmacılar bu durumun olası etkilerinin araştırılması gerektiğini de vurgulamaktadır. Saw ve diğerleri (2013) Amerika'daki 836 Asya kökenli ve 856 Beyaz Amerikalı öğrencinin olduğu örneklemde, etnik köken ve kaygı arasındaki ilişkinin olası arabulucuları olarak ebeveyn beklentileri ve kişisel standartlara göre yaşama algılarını incelenmiştir. Çalışma sonuçlarına göre; Asya kökenli Amerikalı öğrencilerin akademi ve aile ile ilgili kaygıları yüksek çıkmıştır. Ancak bu öğrenciler kaygılarını küresel eğilimler ile ilişkilendirmemişlerdir. Ayrıca çalışma sonucuna göre, etnik köken ebeveyn beklentileri ve kişisel standartlara göre öğrencilerin kaygılarını belirleyen bir unsur olarak tespit edilmiştir.

Guest ve Duyen (2016) öğrencilerin çevrim içi kültür değişim programları (OCEP) ile ilgili yaptıkları tercihlerinin kayg1 ve beklentilerine olan etkilerini Japonya ve Vietnam Öğrencileri üzerine yaptıkları çalışma ile test etmişlerdir. OCEP kapsamında ev sahibi ülke olan Japonya'daki bir üniversite ile Vietnam'daki yeni katılımcı üniversitenin Tıp Fakültesi öğrencilerinden veriler alınarak yapılan bu çalışmada, tıp öğrencilerinin beklentilerini, belirli ilgi alanlarını, tercihlerini, endişelerini ve böylesi bir programa verimli bir şekilde katılma yeteneklerini ölçmek için hazırlanan anket aracılığıyla veriler elde edilmiştir. Bu çalışmada, anketlerin bazı belirgin sonuçları ve programın daha profesyonel ve akademik bir odaklanma 
yönündeki etkileri, katılımcının beklentilerini ve potansiyel sonuçlarını etkileyebilecek kültürün ön planda olduğu faktörler tespit edilmiştir.

Prior ve Cox (2014) öğrencilerin kaygılarını daha ileri yaşları için araştırmışlardır. Bu kapsamda öğrencilerin yaşlanmadan beklentileri ve yaşlılık ile ilgili kaygılarını ölçen araştırmacılar 201 lisans öğrencisi üzerine araştırma yapmışlardır. Öğrenciler tarafından 75 yaşındaki kadın ve erkekler ile temas kurularak yapılan çalışmada erkek katılımcılarda yaşlanmanın daha olumlu beklentileri beraberinde getirdiği sonucu ortaya konarken, kadın katılımcılar için böyle bir sonuç bulunamamıştır. Yani çalışma sonucunda erkek öğrenciler kadın öğrencilere oranla yaşl1lık ile ilgili daha düşük kaygı ve daha yüksek beklentiye sahip olmaktadır.

Turizm eğitimi alan öğrencilerin kayg1 düzeylerini artıran, buna karşın beklenti düzeylerini azaltan pek çok faktör vardır. Bulundukları sektörün endüstriyel beceri istemesi, bireyler arası iletişime dayanması müşteri odaklı ve emek yoğun bir işleyişe sahip olması gibi faktörler bunlardan bir kaçıdır (Kokt ve Strydom, 2014). Çünkü teknolojinin de etkisiyle bireyler artık sosyal bir çalışma ortamının ötesinde mekanik bilgi isteyen işlerde çalışmayı arzulamaktadır. Bu nedenle gelecekte sosyal ilişkiler gerektiren işlerde çalışacak bireylerin kaygı düzeyleri yükssek ve beklentileri düşük olmaktadır.

Üniversite dönemindeki gençlerin ileriki yaşamlarında mutlu olmalarının kaynağı sahip oldukları beklentilerin geçekleşmesidir. Hatta Hawthorne araştırmalarına da yansıdığı gibi verimli çalışmanın kaynağı mutluluk, mutluğunun beklenti düzeylerinin yüksek kaygı düzeylerinin düşük olmasıdır. Bununla birlikte kaygı gibi olumsuz durumların yaşanması olayların kendisinden ziyade, olaylarla ilgili beklentilerdir. Bu duyguların en yoğun yaşandığı kitle ise gençler ve özellikle üniversite öğrencileridir. Özellikle Türkiye'de turizm öğrencilerin beklenti ve kaygı kavramlarının belirgin bir şekilde görüldüğü söylenebilir. Çünkü bu bireylerin üniversite eğitiminden sonraki meslek yaşamlarında özlük hakları ve yasal korunmaları bulunmamaktadır (Üngüren ve Ehtiyar, 2009).

Kokt ve Strydom, (2014) turizm öğrencilerinin beklentilerini ölçerken endüstriyel faktörleri de göz önünde bulundurmuşlardır. Bu kapsamda endüstrideki paydaşların ve turizm öğrencilerinin karşılıklı olarak beklentilerini ölçmeye çalışmışlardır. Araştırmacıların çalışmaları Güney Afrika Bloemfontein bölgesinde gerçekleştirilmiştir. Central University of Technology, Free State (CUT)'da Turizm ve Otelcilik Yönetimi lisans öğrencileri ile Bloemfontein bölgesindeki endüstri paydaşları olmak üzere iki ayrı örneklemden anketler yardımıyla veriler toplanmıştır. Çalışma sonucunda bölgede küçük işletme kurmanın kolay olması nedeniyle birçok öğrencinin kendi işini kurmak istediği yönünde bir sonuç ortaya çıkmıştır. Girişimci olmak istemeyen öğrenciler ise genellikle kongre/konferans ve etkinlik yönetimi/organizasyonu gibi alanlarda çalışmak istemektedirler. Ayrıca çalışma sonucunda öğrencilerin teknik ve yönetim becerilerinin yüksek olması durumunda geleceğe ilişkin beklentilerin daha pozitif olacağı sonucu da elde edilmiştir.

Richardson (2009) öğrencilerin eğitim dönemlerinde olumlu beklentilere sahip olsalar da, iş hayatındaki deneyimlerinden sonra turizm endüstrideki kariyer firsatlarıyla ilgili beklentilerinin olumsuz olabileceğini vurgulamaktadır. Chuang ve diğerleri (2007) alt sınıflarda öğrenim gören öğrencilerin mezun olmaya yakın ve kıdemli öğrencilere kıyasla daha dar kariyer beklentisi aralığına sahip olduklarını ortaya koymaktadır. Çünkü kıdemli öğrenciler staj ve işyeri uygulamaları nedeniyle endüstri ile daha yoğun ilişki içerisindedir.

$\mathrm{Bu}$ çalışmada Türkiye'de turizm eğitimi gören öğrencilerin kaygı ve beklenti düzeylerinin tespit edilmesi, bu kaygı ve beklentilerin ilişkilerinin ortaya konması fikriyle hareket edilmiştir. Türkiye gibi gelişmekte olan ülkelerde, öğrencilerin kaygı ve beklentileri birçok farklı sebepten etkilenebilmektedir. Özellikle ülkenin ekonomik, sosyal ve siyasal yönü 
olan makro unsurlar ile kişisel/mesleki eğitim iş ve aile yapısı gibi mikro unsurlar öğrencilerin kaygı ve beklenti düzey-lerini etkileyen unsurlar olarak ifade edilebilir. Bu anlamda çalışma kapsamında Türkiye'de turizm eğitimi alan öğrencilerin kaygı ve beklenti düzeylerini etkileyen faktörlerin tespit edilmesi de amaçlanmıştır.

\section{YÖNTEM}

$\mathrm{Bu}$ çalışmada Türkiye'de devlet ve vakıf üniversitelerinde turizm eğitimi alan öğrencilerin kaygı ve beklentilerinin araştırılması amaçlanmıştır. Bu kapsamda, öğrencilerin ne tür kayg1 ve kayg1 ve beklentilere sahip olduğu, bu kaygı ve beklentileri etkileyen demografik özelliklerinin neler olduğu, kaygı ve beklentilerine sebep olan faktörlerin neler olduğu, kaygı ve beklentileri düzeyleri arasında nasıl bir ilişkinin olduğu gibi çok boyutlu sonuçlara ulaşılmaya çalışmıştır. Bu çalışmanın sonuçları itibariyle hem literatüre katkı sağlaması hem de Türkiye'de geleceği şekillendiren karar alıcılara yol göstermesi açısından önemli olduğu düşünülmektedir.

\subsection{Katılımeı Profili}

Çalışmanın evreni Türkiye'de turizm eğitimi alan yükseköğretim öğrencileridir. Çalışma kapsamında örnekleme hesaplamasına gidilmemiş ve uygun örnekleme yöntemleri kullanılarak maksimum katılımcıya ulaşılması hedeflenmiştir. Bu kapsamda iki tane olasılığa dayalı olmayan örnekleme türünden yararlanılarak veriler toplanmıştır. İlk olarak veri toplanacak üniversiteler kartopu örnekleme yöntemi ile belirlenmiştir. Araştırmacıların farklı üniversitelerden tanıdıkları ile ilk temas kurulmuştur. Daha sonra temas kurulan bu tanıdıkların farklı üniversitelerden önerdiği ve aracı olduğu kişiler ile ikinci temas sağlanmış ve veri toplanacak üniversiteler belirlenmiştir. Belirlenen üniversitelerden yargısal örnekleme yöntemi örneklem belirlenmiş ve veriler bu şekilde toplanmıştır. Bu kapsamda 10 vakıf ve 20 devlet üniversitesine 100 'er adet anket gönderilerek toplamda 3.000 katılımcıdan veri toplanması hedeflenmiştir. Geri dönüşü sağlanan 2600 anketten hatalı ve eksik doldurulmuş anketler elenmiş ve 2.578 katılımcidan elde edilen veriler analize dâhil edilmiştir.

\subsection{Anket ve Verilerin Analizi}

Araştırmada nicel araştırma tekniklerinden yararlanılarak veriler toplanmıştır. Veri toplama aracı olarak anket tekniği kullanılmıştır. Araştırmada kullanılan anket üç bölümden oluşmaktadır. Birinci bölümde öğrencilerin kaygı ve beklentilerini ölçen ifadeler yer almaktadır. 30 ifadenin yer aldığı bu bölüm için ilk olarak literatür taraması yapılmıştır (Öner ve Le Comte, 1983; Scheier vd., 1986; Güleri, 1998; Malecki ve Demaray, 2002; Emanuel ve Adams, 2006; Douglas, vd., 2006; Ehtiyar ve Üngüren, 2008; McWhirter ve McWhirter, 2008; Dursun ve Aytaç, 2009; Bayoğlu ve Purutçuoğlu, 2010; Tuncer, 2011; Tuncer 2011; Aymankuy ve Aymankuy; 2013; Demir, 2013; Tekin ve Deniz, 2015). Bu çalışmaların tamamı incelendikten sonra araştırma için kullanılacak ölçeğin birinci bölümündeki sorular oluşturulmuştur. Uzman görüşleri de alındıktan sonra bu bölüme son hali verilmiştir. İkinci bölümde, Türkiye'de öğrencilerin kayg1 ve beklentilerini etkileyebilecek faktör yer verilmiştir. Bu bölümde, araştırmacılar tarafından 20 unsur belirlenmiştir. Ancak uzman görüşleri neticesinde elemeler yapılarak anketin son halinde 10 ifadeye yer verilmiştir. Son bölümde ise, öğrencilerin demografik özelliklerini belirlemek adına 7 adet soru kullanılmıştır.

Verilerin analizi için SPSS 24 paket programından yararlanılmıştır. Araştırma kapsamında, analizlerden önce verilere iliş̧in normallik testi yapılmıştır. Bu kapsamda çarpıklık ve basıklık değerlerine de bakılmıştır. Bu değerler hem tek tek bütün ifadeler için, hem de analiz sonucu 
ortaya çıkan faktör boyutları için incelenmiştir. Verilerin normal dağılım şartı için çarpıklık değerinin $-2 / 3$ ile $+2 / 3$ değerleri arasında olması gerektiği bilinmektedir. Basıklık değerinin ise 1,96 ile $+1,96$ değerleri arasında olması gerekmektedir. Likert tipi ölçümlerde eğilim, tutum veya algılamaların zaten bir tarafa meyilli olması beklendiğinden verilerin normal dağılmaması oldukça olasıdır. Bu nedenle Kolmogorov Smirnov ve benzeri normallik ölçen testlere yer verilmeyip normallik şartı çarpıklık ve basıklık değerleri üzerinden ele alınmıştır. (Tabachnick ve Fidell, 2013: 204-204). Araştırma kapsamında bakılan ifadelerin çarpıklık ve basıklık değerleri bu referans değerler aralığında olduğu için verilerin normal dağıldığ 1 varsayılmıştır. Bu nedenle verilerin analizinde parametrik testlerden yararlanılmıştır.

\subsection{Araştırmanın Geçerlilik ve Güvenilirliği}

Çalışmada kullanılan ankete ilişkin geçerlilik şartının sağlanması için bazı uygulamalar yapılmıştır. Özellikle yüzey ve kapsam geçerlilik bağlamında, çalışmada kullanılan anketin literatürdeki birçok çalışmada kullanılan ifadelerden oluşması ve anketin son halinin uzmanlardan görüşler alınarak oluşturulması çalışmanın geçerliliği konusunda önemli bir referanstır. Bununla birlikte Sakarya Uygulamalı Bilimler Üniversitesi Turizm Fakültesinden toplanan 100 adet anket üzerinde bir pilot çalışma yapılmış ve bu çalışma neticesinde araştırmada kullanılan anketin araştırma problemine cevap verecek nitelikte olduğu görülmüştür. Ayrıca, veri toplama süreci tamamlandıktan sonra elde edilen veri seti devlet ve vakıf üniversiteleri için ayrı ayrı değerlendirilmiş ve iki ayrı veri seti üzerinde yapılan güvenilirlik ve frekans analizleri için benzer sonuçların ortaya çıktığı görülmüştür. Güvenilirlik için Cronbach Alpha (0-1 aralığında değerler alır) değerine bakılmıştır. Çalışmada kullanılan ölçeğin genel güvenilirliği için Alpha değeri 0,853 olarak tespit edilmiştir. Kaygı ve beklenti düzeylerine ilişskin ifadelerin yer aldığ faktörlerin yer aldığ i ikinci bölüm için ise 0,811 olarak bulunmuştur. 0,70 üzerindeki değerlerin yüksek güvenilir kabul edildiği sosyal bilimler için bu değerler güvenilirlik şartının sağlandığını göstermektedir (Altunışık, vd., 2012: 126).

\section{BULGULAR}

Araştırma bulgularının elde edilmesinde farklı analiz tekniklerinden yararlanılmıştır. Öğrencilerin kaygı ve beklenti gibi benzer niteliklerini ölçen değişkenleri bir araya toplayarak az sayıda faktörle açıklamak için faktör analizi yapılmıştır (Büyüköztürk, 2005: 123). Öğrencilerin kaygı ve beklentilerinde demografik değişkenlerin belirleyici olup olmadığının tespit edilmesi için farklılık testlerinden T-testi ve Anova testlerinden yararlanılmıştır. Öğrencilerin kaygı ve beklentilerini etkileyen faktörlerin tespit edilmesi için frekans tablosu raporlanmıştır. Son olarak kayg1 ve beklentiye ilişkin oluşan boyutlar arasındaki ilişkinin tespiti amacıyla korelasyon analizinden faydalanılmıştır.

Ön değerlendirme sonucu hatalı olduğu tespit edilen anketler analiz sürecinde dikkate alınmamıştır. Sadece eksik kısımların çok az olduğu anketler analizlere dâhil edilmiştir. Altunışık ve arkadaşları (2012: 153) kayıp verisi \%10'un altında olan anketlerin araştırmaya dahil edilebilir olduğunu ifade etmektedir. Bu nedenle anketin tamamında likert ve demografik kısımlar kendi içerisinde değerlendirilmiş ve her bölüm için sadece iki soruya kadar eksik olan anketler analize dâhil edilmiştir. Bu nedenle analiz sonucunda ortaya çıkan kayıp veriler raporlamalarda devre dışı bırakılmıştır. Tablolardaki sayılar için toplam anket sayısından kayıp verilerin düşürülmesiyle değerlendirmeler yapılmıştır. 


\subsection{Betimleyici İstatistikler}

Demografik değişkenlere ilişkin betimleyici istatistiklere ait bulguları içeren Tablo 1 incelendiğinde, katılımcıların cinsiyet ve eğitim görülen üniversite türleri bakımından dengeli bir dağılıma sahip oldukları görülmektedir.

Tablo 1: Katılımcılara İlişkin Betimleyici İstatistikler

\begin{tabular}{|c|c|c|c|c|c|}
\hline De g g işken le r & Sayı & $\%$ & De g g işken le r & Sayı & $\%$ \\
\hline Cinsiyet & -- & $\overline{---}$ & Katılımcıların Gelir Kaynağı & 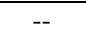 & -- \\
\hline Kadın & 1.293 & 50,5 & Aileden & 1.326 & 53,2 \\
\hline Erkek & 1.265 & 49,5 & Burs ve Kredi & 656 & 26,3 \\
\hline YaşGruplart & -- & -- & Çalışıyorum & 576 & 20,5 \\
\hline 20 Yaş altı & 509 & 19.9 & $\begin{array}{l}\text { Katılımcıların Ĕ̈itim Gördükleri } \\
\text { Üniversite Türü̈ }\end{array}$ & -- & -- \\
\hline 20-22 Yaş & 1.316 & 51.5 & Devlet Üniversitesi & 1.158 & 45,5 \\
\hline 23-25 Yaş & 514 & 20.1 & Vakıf Üniversitesi & 1.385 & 54,5 \\
\hline 25 Yaş üstü & 212 & 8.5 & & & \\
\hline Katılımcıların Eğitim Düzeyi & & & Katılımcıların Ailelerinin İkamet Yeri & -- & -- \\
\hline Önlisans & 666 & 26.1 & Marmara Bölgesi & 1318 & 51.6 \\
\hline Lisans & 1.743 & 68.4 & Ege Bölgesi & 248 & 9.7 \\
\hline Lisansüstü & 139 & 5.5 & Karadeniz Bölgesi & 382 & 15 \\
\hline Katılımcıların Aylık Geliri & -- & -- & Akdeniz Bölgesi & 141 & 5.5 \\
\hline 500 TL ve altı & 788 & 30.9 & İç Anadolu Bölgesi & 251 & 9.8 \\
\hline $501-700 \mathrm{TL}$ & 478 & 18.7 & Doğu Anadolu Bölgesi & 121 & 4.7 \\
\hline 701-1.000 TL & 524 & 20.5 & Güneydoğu Anadolu Bölgesi & 89 & 3.7 \\
\hline $1.001 \mathrm{TL}$ ve üzeri & 757 & 29.3 & & & \\
\hline
\end{tabular}

Tablo 1'de görüldüğü üzere; Katılımcıların yarısından fazlasının (\%51) ailesi Marmara Bölgesi'nde ikamet etmektedir. Karadeniz Bölgesi'nde ikamet edenlerin oranı \%15, İç Anadolu Bölgesi'nde ikamet edenlerin oranı $\% 9,8$ ve ankete katılan katılımcıların \%3,7'sinin ailesi ise Güneydoğu Anadolu Bölgesi'nde ikamet etmektedir. Katılımcıların yarısından fazlası $(\% 51,5)$ 20-22 yaş grubu öğrencilerden oluşmaktadır. 23-25 yaş arasında olan katılımcıların oranı $\% 20,1$, 20 yaş altı katılımcıların oranı $\% 19,9$ iken 25 yaş üstü katılımcı oranı ise $\% 8,5$ 'dir. Katılımcıların aylık gelirleri dengeli bir dağılım göstermekle birlikte, $500 \mathrm{TL}$ ve altındaki öğrenciler yaklaşık \%31 ile çoğunluğu oluştururken, katılımcıların gelir kaynakları arasında ailelerinin pay1 \%53,2 olduğu görülmektedir. Tablo 1'de, burs ve kredi ile öğrenimlerini devam ettirenlerin oranlarının ise $\% 26,3$ olduğu ifade edilmiştir.

\subsection{Kaygı ve Beklentilere ilişkin Faktör Analizi}

Bu çalışmada kaygı ve beklenti ölçeğindeki ifadelerin sayıca azaltılması ve araştırma sonuçlarının daha anlaşılır olması için açıklayıcı faktör analiz yapılmıştır. Kaiser-Meyer-Olkin (KMO) değeri 0,946 $(\mathrm{KMO}>0,70), \mathrm{p}$ değeri $0,000(\mathrm{p}<0,05)$ olarak tespit edilmiştir. KMO ölçütünün 0 ile 1 arasında değer aldığını; 0,70 ve üzeri değer almasının örneklem yeterliliği hususunda kabul edilebilir düzeyde olduğunu göstermektedir. Ayrıca, Bartlett Küresellik Testi ile "faktör boyutları arasındaki ilişki anlamlıdır." hipotezi test edilmiş ve hipotez kabul edilmiştir. Açıklayıcı faktör analizi neticesinde 4 faktör bulunmuş bu faktörler "Mesleki Beklentiler", "Kişisel Beklentiler", "Toplumsal Beklentiler" ve "Mesleki ve Toplumsal Kaygılar" olarak adlandırılmıştır. Bu boyutlar Tablo 2'de verilmektedir. Bu değerler yapılan faktör analizinin istatistiksel olarak anlamlı olduğunu göstermektedir.

Tablo 2. Faktör Analizi Bulguları

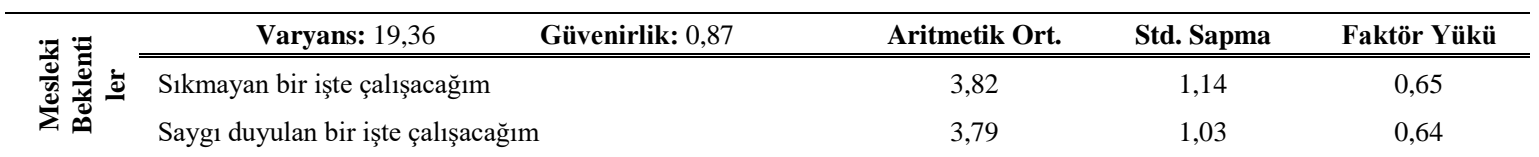




\author{
Kazancı bol bir işte çalışacağım \\ Entelektüel kişilerle birlikte olacağım \\ Benimle gurur duyulacak bir mesleğim olacak \\ Yapacağım işten zevk alacağım \\ Yeteneklerimi göstereceğim bir işte çalışacağım \\ Yapacağım iş bana lüks bir hayat sunacak \\ Yükselebilme imkânı olan bir işte çalışacağım \\ Varyans: 16,24 \\ Geçim sıkıntısı çekmeyeceğim \\ Düzenli bir işim olacak \\ Kendimi güvende hissedeceğim
Iyi bir işim olacak
Intiyacım olan şeyleri alabileceğim
Mutlu bir hayatım olacak \\ Seçeceğim meslek geleceğimi güven altına alacak \\ İstediğim eğitim düzeyine ulaşacağım
}

Gelenek ve göreneklerimi yaşatacağım

\section{竞}

Varyans: 7,32

Güvenirlik: 0,59

Toplum yapısı aile düzenini etkileyecek

Gelecekte toplumsal baskılarla karşılaşacağım

Yapacağım işte devamlı aynı statüde kalacağım

Yapacağım iş özel yaşamıma engel olacak

$\begin{array}{lll}3,66 & 1,06 & 0,63 \\ 3,30 & 1,07 & 0,63 \\ 3,82 & 1,14 & 0,62 \\ 3,99 & 1,06 & 0,61 \\ 3,77 & 1,11 & 0,54 \\ 3,97 & 1,04 & 0,54 \\ 3,97 & 1,04 & 0,52\end{array}$

Aritmetik Ort.
3,91
3,76
3,84
3,82
3,83
3,77
3,77
3,84
3,69
3,86

Std. Sapma

Faktör Yükü

0,97

0,74

0,98

0,73

1,02

0,71

0,97

0,68

0,94

0,61

1,02

0,58

0,58

0,56

1,03

0,55

1,05

0,46

Aritmetik Ort.

3,84

1,10

Std. Sapma

Faktör Yükü

0,79

0,79

0,79

1,04

0,76

Aritmetik Ort.

Std. Sapma

Faktör Yükü

2,87

1,19

0,79

1,19

1,20

0,71

0,79

1,16

0,62

0,53

Varimaks Rotasyonlu Temel Bileşenler Analizi: Açıllanan Toplam Varyans: \%53,13; KMO (Kaiser-Meyer-Olkin) Örneklem Büyüklüğ̈̈: \%94,6; Barlett Küresellik Testi: $p<0,05$; df: 325-Ki-Kare: 2675,739; Değerlendirme Arallğı: Bütün Boyutlar için (1) Kesinlikle Katılmuyorum- (2) Kesinlikle Katıllyorum.

Boyutlara ilişkin toplam açıklanan varyans \%53,13 bulunmuştur. Bu sonuç sosyal bilimlerdeki çalışmalar için önemli bir oran olarak kabul edilmektedir (Can, 2014: 305). Boyutlardaki en yüksek açılanan varyans değeri ise \%19,36 ile "Mesleki Beklentiler" boyutuna aittir. Aritmetik ortalamalara bakıldığında ise, beklenti boyutlarında bu değer orta değer olan 3'ün üstünde iken kaygı boyutunda 3'ün altındadır.

\subsection{Kaygı Beklentileri Belirlemede Rol Oynayan Değişkenlere İlişkin Farklılık Testleri}

Öğrencilerin kayg1 ve beklenti düzeylerinin cinsiyetlerine göre yapılan farklılık analizinin bulguları Tablo 3'te verilmektedir. Bu sonuçlara bakıldığında, "Mesleki Beklentiler" dışındaki boyutların cinsiyete göre farklık gösterdiği görülmektedir. Beklenti boyutlarından "Kişisel Beklentiler" ve "Toplumsal Beklentiler" boyutlarında meydana gelen farklılık erkeklerin kadınlar-dan daha olumlu düşünmelerinden kaynaklanmaktadır. Yani, erkekler kadınlara oranla daha çok beklentiye sahiptir. "Mesleki ve Toplumsal Kaygılar" boyutundaki 
farklılık, kadınların erkeklere oranla daha olumlu düşünmelerinden kaynaklanmaktadır. Kadınlar ise erkeklere oranla daha fazla mesleki ve toplumsal kaygılara sahiptir.

Tablo 3. Öğrencilerin Cinsiyetlerine Göre Kaygı ve Beklentiler

\begin{tabular}{|c|c|c|c|c|c|}
\hline If adeler & $D e \breve{g} i s ̧ k e n$ & $n$ & A.O. & $t$ & $p$ \\
\hline \multirow{2}{*}{ Mesleki Beklentiler } & Erkek & 1.293 & 3,90 & \multirow{2}{*}{1,16} & \multirow{2}{*}{0,09} \\
\hline & Kadın & 1.265 & 3,85 & & \\
\hline Kişisel Beklentiler & Kadın & 1.265 & 3,70 & 3,00 & $0,003 *$ \\
\hline Toplumsal Beklentiler & Erkek & 1.293 & 3,90 & 2,19 & $0,03 *$ \\
\hline Mesleki ve Toplumsal Kaygilar & Kadın & 1.265 & 2,89 & $-2,49$ & $0,01 *$ \\
\hline
\end{tabular}

*p<0,05 olduğu için anlamlıdır. Burada “ $n$ ” sayıl, A.O. aritmetik ortalamayl, $t$ : $t$-istatistik değerini ve " $p$ ” olasılık değerini göstermektedir.

Tablo 4'te öğrencilerin kaygı ve beklentilerinin okudukları üniversite türlerine göre yapılan farklı1ık analizleri yer almaktadır. Konu ile ilgili kaygı ve beklenti boyutlarından sadece "Toplumsal Beklentiler" boyutunda anlamlı bir farklılık tespit edilmiştir.

Tablo 4. Öğrencilerin Üniversite Türlerine Göre Kaygı ve Beklenti Analizi

\begin{tabular}{|c|c|c|c|c|c|}
\hline If adeler & Değişken & $n$ & A.O. & $t$ & $p$ \\
\hline \multirow{2}{*}{ Mesleki Beklentiler } & Devlet Üniversitesi & 1.158 & 3,87 & \multirow{2}{*}{$-0,59$} & \multirow{2}{*}{0,55} \\
\hline & Vakıf Üniversitesi & 1.385 & 3,89 & & \\
\hline \multirow{2}{*}{ Kişisel Beklentiler } & Devlet Üniversitesi & 1.158 & 3,76 & \multirow{2}{*}{0,44} & \multirow{2}{*}{0,66} \\
\hline & Vakıf Üniversitesi & 1.385 & 3,75 & & \\
\hline \multirow{2}{*}{ Toplumsal Beklentiler } & Devlet Üniversitesi & 1.158 & 3,92 & \multirow{2}{*}{2,81} & \multirow{2}{*}{$0,01 *$} \\
\hline & Vakıf Üniversitesi & 1.385 & 3,81 & & \\
\hline \multirow{2}{*}{ Mesleki ve Toplumsal Kaygilar } & Devlet Üniversitesi & 1.158 & 2,87 & \multirow{2}{*}{1,05} & \multirow{2}{*}{0,39} \\
\hline & Vakıf Üniversitesi & 1.385 & 2,83 & & \\
\hline
\end{tabular}

Aritmetik ortalamalar incelendiğinde, bu farklılı̆̆ın devlet üniversitelerinde okuyan öğrencilerin vakıf üniversitelerde okuyanlara oranla daha olumlu düşünmelerinden kaynaklandığı görülmektedir. Devlet üniversitelerinde okuyanlar öğrenciler vakıf üniversitelerde okuyanlara göre daha fazla toplumsal beklentiye sahiptir. Öğrencilerin kaygı ve beklentilerinin yaşlarına göre farklılaşıp farklılaşmadığ 1 ile ilgili elde edilen bulgular Tablo 5'te verilmiştir. Gruplar arası varyansların eşit dağıldığı varsayımı ihlal edildiğinden, yaş değişkeni için farklılık tespit edilirken nonparametrik testlerden Kruskal Wallis testinden yararlanılmıştır.

Tablo 5. Öğrencilerin Yaşlarına Göre Kaygı ve Beklenti Analizi

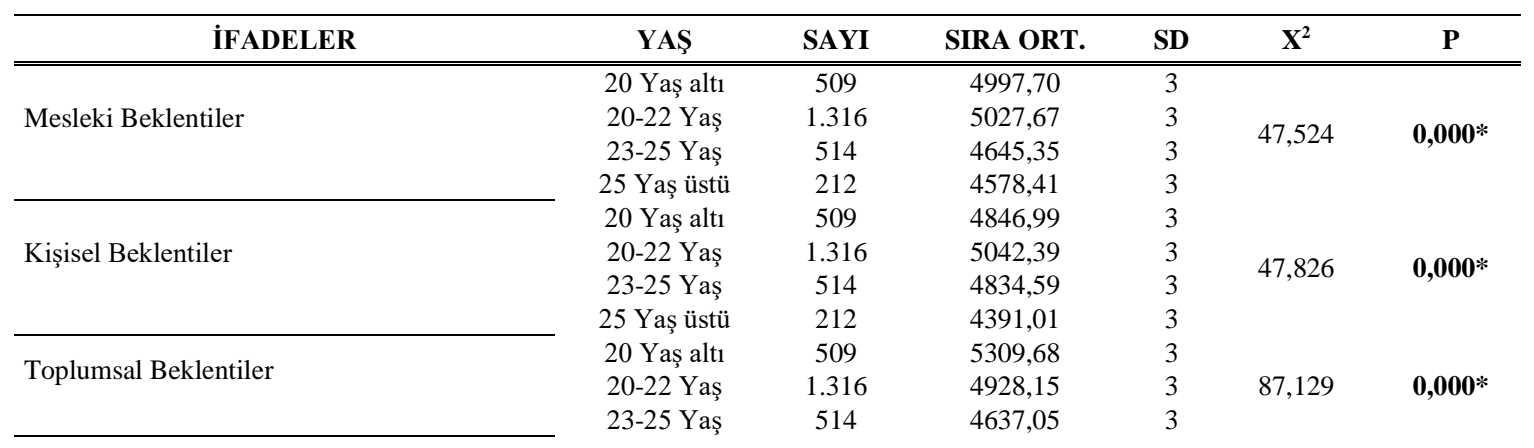




\begin{tabular}{|c|c|c|c|c|c|c|}
\hline & 25 Yaş üstü & 212 & 4469,23 & 3 & & \\
\hline \multirow{3}{*}{ Mesleki ve Toplumsal Kaygilar } & 20 Yaş altı & 509 & 4981,03 & 3 & \multirow{3}{*}{14,648} & \multirow{3}{*}{$\mathbf{0 , 0 0 2} *$} \\
\hline & 20-22 Yaş & 1.316 & 4816,86 & 3 & & \\
\hline & 23-25 Yaş & 514 & 4995,57 & 3 & & \\
\hline
\end{tabular}

*p<0,05 olduğu için anlamlıdır. Burada “ $p$ ” olasılık değerini göstermektedir.

Tablo 5'te, beklentilerle ilgili olan her üç boyutta da anlamlı farklılık tespit edilmiştir. "Mesleki Beklentiler" ve "Kişisel Beklentiler" boyutlarındaki farklılık 20-22 yaş grubu ile 25 üzeri yaş grupları arasında oluşmaktadır. 20-22 yaş grubundaki öğrenciler daha fazla beklenti taşımaktadır. "Toplumsal Beklentiler" boyutundaki farklılık ise 20 yaş altı grubu ile 23-25 ve 25 üzeri yaş grupları arasında gerçekleşmiştir. 20 altı yaş grubundaki öğrenciler toplumsal beklenti konusunda daha olumlu görüşlere sahiptir. Şu halde, örneklem kapsamındaki öğrencilerin yaşları düştükçe beklentileri artmaktadır diyebiliriz. "Mesleki ve Toplumsal kaygılar" boyutu da anlamlı farkl11ık göstermektedir. Buradaki farklılık ise beklentilerin tersine sonuçlar vermektedir. Öğrencilerin yaşları büyüdükçe kaygıları artmaktadır.

Tablo 6'da öğrencileri kaygı beklentilerinin eğitim düzeylerine olan farklılık analizine ilişkin bulgulara yer verilmektedir. Gruplar arası varyansların eşit dağıldığı varsayımı ihlal edildiğinden, eğitim değişkeni için farklılık tespit edilirken nonparametrik testlerden Kruskal Wallis testinden yararlanılmıştır. Tablo 6'da, "Mesleki Beklentiler", "Kişisel Beklentiler" ve "Toplumsal Beklentiler" boyutlarında anlamlı farklılıklar tespit edilmişstir. Yani her üç beklenti boyutu da eğitim değişkenine göre anlamlı farklılık göstermiştir. "Mesleki Beklentiler" ve "Kişisel Beklentiler" boyutlarındaki farklılık lisansüstü eğitim düzeyi ile önlisans ve lisans eğitim düzeyleri arasında gerçekleşmiştir. Lisansüstü öğrencileri diğer iki gruba göre daha olumsuz görüş taşımaktadır. "Toplumsal Beklentiler" boyutundaki farklılık ise, önlisans ile lisans eğitim düzeyleri arasında gerçekleşmiştir. Lisans öğrencileri ön lisanstakilere göre daha olumsuz düşünmektedir. Türkiye'de eğitim düzeyi yükseldikçe öğrencilerin beklentileri azalmaktadır. Mesleki ve Toplumsal kaygılar boyutu ise eğitim durumuna göre anlamlı farklılık göstermemektedir.

Tablo 6. Öğrencilerin Eğitim Düzeylerine Göre Kaygı ve Beklenti Analizi

\begin{tabular}{|c|c|c|c|c|c|c|}
\hline IFADELER & EĞİTIM DURUMU & SAYI & SIRA ORT. & SD & $\mathrm{X}^{2}$ & $\mathbf{P}$ \\
\hline \multirow{3}{*}{ Mesleki Beklentiler } & Ön Lisans & 666 & 5257,31 & 2 & \multirow{3}{*}{73,237} & \multirow{3}{*}{$\mathbf{0 , 0 0 0}$} \\
\hline & Lisans & 1.743 & 4792,71 & 2 & & \\
\hline & Lisansüstü & 139 & 4546,22 & 2 & & \\
\hline \multirow{3}{*}{ Kişisel Beklentiler } & Ön Lisans & 666 & 4925,77 & 2 & \multirow{3}{*}{10,883} & \multirow{3}{*}{0,004} \\
\hline & Lisans & 1.743 & 4923,39 & 2 & & \\
\hline & Lisansüstü & 139 & 4540,08 & 2 & & \\
\hline Toplumsal Beklentiler & Lisansüstü & 139 & 4477,66 & 2 & 87,770 & $\mathbf{0 , 0 0 0}$ \\
\hline \multirow{3}{*}{ Mesleki ve Toplumsal Kaygilar } & Ön Lisans & 666 & 4893,97 & 2 & \multirow{3}{*}{2,029} & \multirow{3}{*}{0,362} \\
\hline & Lisans & 1.743 & 4894,63 & 2 & & \\
\hline & Lisansüstü & 139 & 5063,59 & 2 & & \\
\hline
\end{tabular}

* $p<0,05$ olduğu için anlamlıdır. Burada " $p$ ” olasılık değerini göstermektedir

Tablo 7'de, öğrencilerin gelir durumlarına göre kaygı ve beklenti analizi sonuçları verilmiş-tir. Tablo 7 incelendiğinde, sadece "Toplumsal Beklentiler" boyutunda bir anlamlı farklılığın tespit edildiği görülmektedir. Farklılık 500 TL ve altı gelir grubundaki öğrenciler ile 701-1000 TL ve 1001 TL ve üzeri gruplarındaki öğrenciler arasında gerçekleşmiştir. 500 TL ve daha az gelire sahip ögrenciler, toplumsal beklentiler konusunda diğer gruplara göre daha olumlu düşünmekte, yani daha fazla toplumsal beklenti taşımaktadırlar. 
Tablo 7. Öğrencilerin Gelir Durumlarına Kaygı ve Beklenti Analizi

\begin{tabular}{|c|c|c|c|c|c|c|c|}
\hline Boyutlar & $F$ & $p$ & $\begin{array}{l}500 \text { TL ve } \\
\text { alt A.O. }\end{array}$ & $\begin{array}{l}501-700 \\
\text { TL A.O. }\end{array}$ & $\begin{array}{l}\text { 701-1.000 } \\
\text { TL A.O. }\end{array}$ & $\begin{array}{l}\text { 1.001 TL ve } \\
\ddot{U z e r i} \text { A.O. }\end{array}$ & Tukey \\
\hline $\begin{array}{l}\text { Mesleki } \\
\text { Beklentiler }\end{array}$ & 1,066 & 0.094 & 3,732 & 3,767 & 3,713 & 3,788 & Farkl111k yoktur. \\
\hline $\begin{array}{l}\text { Kişisel } \\
\text { Beklentiler }\end{array}$ & 2,137 & 0.362 & 3,869 & 3,815 & 3,864 & 3,932 & Farklıl1k yoktur. \\
\hline $\begin{array}{l}\text { Toplumsal } \\
\text { Beklentiler }\end{array}$ & 6,320 & $0.000 *$ & 3,978 & 3,849 & 3,795 & 3,783 & $\begin{array}{l}500 \mathrm{TL} \text { ve Alt } / 701-1.000 \mathrm{TL} \text {, } \\
1.001 \mathrm{TL} \text { ve Üzeri }\end{array}$ \\
\hline $\begin{array}{l}\text { Mesleki ve } \\
\text { Toplumsal } \\
\text { Kaygilar }\end{array}$ & 2,555 & 0.054 & 2,838 & 2,826 & 2,944 & 2,809 & Farkl1l1k yoktur. \\
\hline
\end{tabular}

$*_{p<0,05}$ olduğu için anlamlıdır. Burada A.O. aritmetik ortalamayı ve " $p$ ” olasılık değerini göstermektedir.

Tablo 8'de öğrencilerin gelir kaynaklarına göre kaygı ve beklenti analizi sonuçları verilmiştir. Tablo 8 incelendiğinde, "Mesleki Beklentiler" ve "Toplumsal Beklentiler" boyutlarının öğrencilerin gelir kaynaklarına göre farklılaştı̆̆ 1 görülmektedir. Her iki boyutta da farklılık daha çok gelirlerini ailelerinden elde edenlerin çalışarak elde edenlere oranla daha olumlu düşünmelerinden kaynaklanmaktadır. Türkiye'de gelirlerini ailelerinden elde eden öğrenciler, gelirlerini çalışarak elde edenlere göre daha fazla beklenti içerisindedir. "Mesleki ve Toplumsal Kaygilar" boyutundaki farkl1l1k ise, gelirlerini ailelerinden elde edenler ile burs-kredi ve çalışarak elde edenler arasında gerçekleşmiştir. Gelir kaynakları açısında en çok kaygı taşıyanlar sırasıyla Burs-kredi, aile ve çalışarak gelir elden eden gruplar şeklinde gerçekleşmektedir.

Tablo 8. Öğrencilerin Gelir Kaynaklarına Göre Kaygı ve Beklenti Analizi

\begin{tabular}{|c|c|c|c|c|c|c|}
\hline Boyutlar & $\boldsymbol{F}$ & $p$ & Aile A.O. & $\begin{array}{c}\text { Burs-Kredi } \\
\text { A.O. } \\
\end{array}$ & $\begin{array}{l}\text { Çalışıyorum } \\
\text { A.O. } \\
\end{array}$ & Tukey \\
\hline Mesleki Beklentiler & 9,079 & $0,000^{*}$ & 3,815 & 3,739 & 3,627 & Aile/Çalışyorum \\
\hline Kişisel Beklentiler & 1,300 & 0,273 & 3,903 & 3,844 & 3,861 & Farklılık yoktur \\
\hline Toplumsal Beklentiler & 4,652 & $0,01 *$ & 3,891 & 3,904 & 3,750 & Aile/Çalışıyorum \\
\hline $\begin{array}{l}\text { Mesleki ve } \\
\text { Toplumsal Kaygılar }\end{array}$ & 8,871 & $0,000 *$ & 2,779 & 2,955 & 2,884 & Aile/Burs ve Kredi \\
\hline
\end{tabular}

*p<0,05 olduğu için anlamlıdır. Burada “A.O.” aritmetik ortalamayı ve “p” olasıllk değerini göstermektedir.

Tablo 9'da öğrencilerin ailelerinin ikamet ettikleri bölgelere göre kaygı ve beklenti analizine ilişkin sonuçlar yer almaktadır. Gruplar arası varyansların eşit dağıldığı varsayımı ihlal edildiğinden, öğrencilerin ailelerinin ikamet ettikleri bölge değişkeni için farklılık tespit edilirken non-parametrik testlerden Kruskal Wallis testinden yararlanılmıştır. Çalışma kapsamındaki her dört boyut için de anlamlı farklılık tespit edilmiştir. "Mesleki Beklentiler" boyutu için farklılık ailesi Marmara bölgesinde yaşayanlar ile Güneydoğu Anadolu bölgesinde yaşayanlar arasında gerçekleşmiştir. Güneydoğu Anadolu bölgesindeki ailelerin çocukları daha yüksek mesleki beklenti içerisindedir. "Kişisel Beklentiler" boyutundaki farklılık Akdeniz bölgesinde yaşayanlar ile Marmara ve Ege bölgesinde yaşayanlar arasında gerçekleşmektedir. Akdeniz bölgesindeki ailelerin çocukları diğer iki bölgedekilere göre daha olumlu kişisel beklentilere sahiptir. "Toplumsal Beklentiler" boyutundaki farklılık ise Güneydoğu Anadolu ve Doğu Anadolu bölgeleri ile Marmara ve Ege bölgeleri arasında gerçekleşmektedir. Ailesi Doğu ve Güneydoğu Anadolu bölgesinde ikamet eden gençler, Marmara ve Ege bölgesinde ikamet edenlere göre daha fazla toplumsal beklenti içerisindedir. 
Tablo 9. Öğrencilerin Ailelerinin İkamet Ettikleri Bölgelere Göre Kaygı ve Beklenti Analizi

\begin{tabular}{|c|c|c|c|c|c|c|}
\hline İFADELER & BÖLGE & SAYI & SIRA ORT. & SD & $\mathbf{X}^{2}$ & $\mathbf{P}$ \\
\hline \multirow{7}{*}{ Mesleki Beklentiler } & Marmara & 1318 & 4860,09 & 6 & \multirow{7}{*}{29,236} & \multirow{7}{*}{$0,000 *$} \\
\hline & Karadeniz & 382 & 5017,96 & 6 & & \\
\hline & İç Anadolu & 251 & 4772,59 & 6 & & \\
\hline & Ege & 248 & 5012,73 & 6 & & \\
\hline & Doğu Anadolu & 121 & 4779,02 & 6 & & \\
\hline & Güney D. Anadolu & 89 & 5500,03 & 6 & & \\
\hline & Akdeniz & 141 & 4858,62 & 6 & & \\
\hline \multirow{7}{*}{ Kişisel Beklentiler } & Marmara & 1318 & 4860,55 & 6 & \multirow{7}{*}{19,564} & \multirow{7}{*}{$0,003 *$} \\
\hline & Karadeniz & 382 & 4988,55 & 6 & & \\
\hline & İç Anadolu & 251 & 4966,51 & 6 & & \\
\hline & Ege & 248 & 4738,73 & 6 & & \\
\hline & Doğu Anadolu & 121 & 4864,99 & 6 & & \\
\hline & Güney D. Anadolu & 89 & 5169,61 & 6 & & \\
\hline & Akdeniz & 141 & 5227,37 & 6 & & \\
\hline \multirow{7}{*}{ Toplumsal Beklentiler } & Marmara & 1318 & 4841,00 & 6 & \multirow{7}{*}{65,854} & \multirow{7}{*}{$0,000 *$} \\
\hline & Karadeniz & 382 & 5332,10 & 6 & & \\
\hline & İç Anadolu & 251 & 4969,56 & 6 & & \\
\hline & Ege & 248 & 4688,31 & 6 & & \\
\hline & Doğu Anadolu & 121 & 4955,97 & 6 & & \\
\hline & Güney D. Anadolu & 89 & 5175,95 & 6 & & \\
\hline & Akdeniz & 141 & 4477,44 & 6 & & \\
\hline \multirow{7}{*}{ Mesleki ve Toplumsal Kaygılar } & Marmara & 1318 & 4729,06 & 6 & \multirow{7}{*}{66,611} & \multirow{7}{*}{$0,000 *$} \\
\hline & Karadeniz & 382 & 5113,02 & 6 & & \\
\hline & İç Anadolu & 251 & 5291,76 & 6 & & \\
\hline & Ege & 248 & 4852,00 & 6 & & \\
\hline & Doğu Anadolu & 121 & 5329,85 & 6 & & \\
\hline & Güney D. Anadolu & 89 & 4955,79 & 6 & & \\
\hline & Akdeniz & 141 & 5091,85 & 6 & & \\
\hline
\end{tabular}

* $p<0,05$ olduğu için anlamlıdır. Burada " $p$ " olasıllı̆̆ göstermektedir.

"Mesleki ve Toplumsal Kaygılar" boyutunda anlamlı farkl1lık aileleri Marmara bölgesinde ikamet edenler ile diğer coğrafi bölgelerde ikamet eden öğrenci grupları arasında gerçekleşmiştir. Aileleri Marmara bölgesinde ikamet edenler diğer bölgelerde ikamet edenlere göre daha az mesleki ve toplumsal kaygı taşımaktadırlar.

\section{4. Öğrencilerin Kaygı ve Beklentilerini Etkileyen Faktörler}

Tablo 10'da, katılımcıların kaygı ve beklentilerini etkileyen faktörlere ilişkin sonuçlar verilmiştir. Burada kaygı ve beklentilerini etkileyen faktörler olarak aile yapısı ve aile baskısı, terör, üniversite eğitimi, ekonomik istikrarsızlık, demokrasi ve insan hakları düzeyi, eğitimsektör uyumsuzluğu, iş ve yatırım oranı, siyasal istikrarsızlık, bürokrasi ve politik istikrarsızlık gibi farklı faktörlere yer verilmiştir.

Tablo 10. Katılımcıların Kaygı ve Beklentilerini Etkileyen Faktörlere İlişkin Bulgular

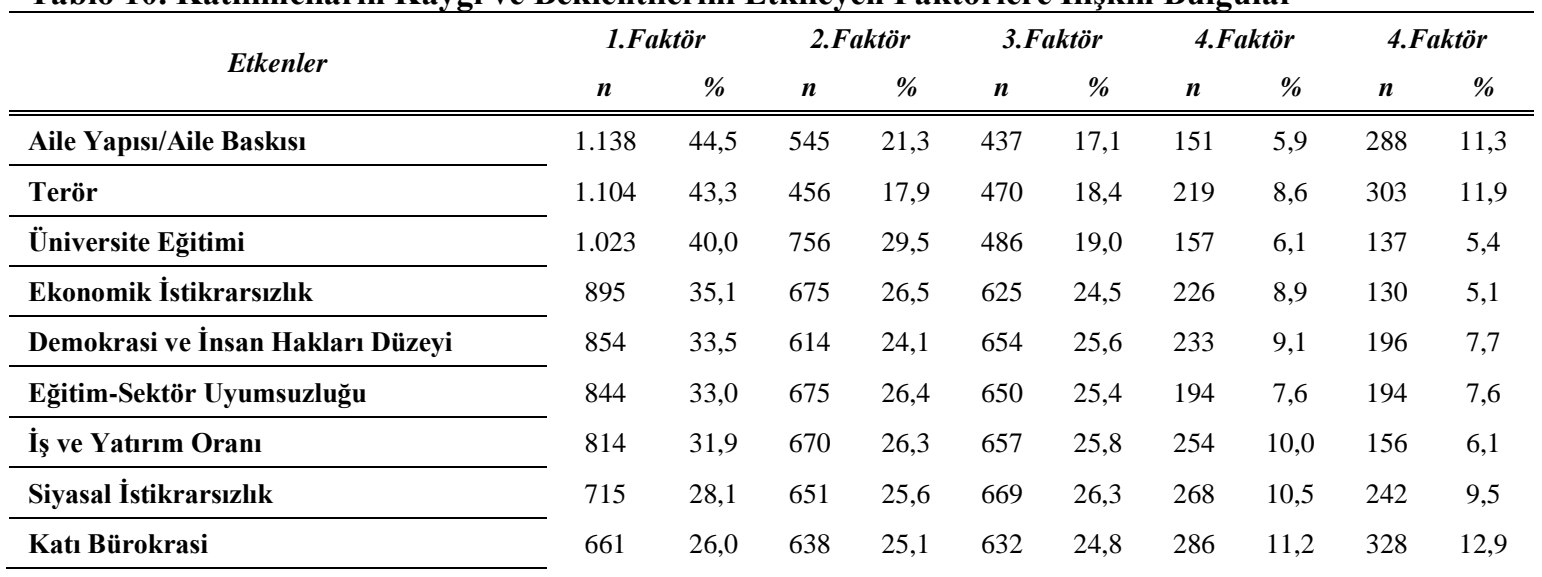


\begin{tabular}{lllllllllll}
\hline Politika İstikrarsızlı̆ & 624 & 24,4 & 698 & 27,3 & 725 & 28,4 & 273 & 10,7 & 236 & 9,2 \\
\hline
\end{tabular}

“n” saylyı göstermektedir.

Araştırma kapsamında öğrencilerin gelecekle ilgili kaygı ve beklentilerini etkileyen faktörleri belirtmeleri istenmiştir. Böylece öğrencilerin kayg1 ve beklentilerini etkileyen faktörlerden en çok hangilerinin birinci faktör olarak ifade edileceği belirlenmeye çalışılmıştır. Analiz sonucunda \%44,5 ile aile yapısı/aile baskısı öğrencilerin geleceğe ilişkin kaygı ve beklentilerini etkileyen faktörler arasında en çok birinci etken olarak belirtilen faktör olmuştur. Bunu \%43,3 ile terör izlerken, \%40 ile üniversite eğitimi takip etmektedir. Bunları dördüncü olarak ekonomik istikrarsızlık takip etmektedir. Bu konudaki en ilginç veri ise siyasi istikrarsızlık, politik istikrarsızlık ve katı bürokrasi gibi ülkenin ekonomik ve siyasi durumuyla ilgili faktörlerin kaygı ve beklentiyi etkileyen en az birinci faktör olarak yer almasıdır.

\section{5. Öğrencilerin Kaygı ve Beklentileri Arasındaki İlişki}

Öğrencilerin kaygı ve beklenti düzeylerinin ilişkilerine yönelik yapılan korelasyon analizi Tablo 11'de verilmektedir. Korelasyon analizi değişkenler arasındaki ilişkinin yönü ve şiddeti hakkında bilgiler sunmaktadır. Korelasyon katsayıları -1 ile +1 arasında değerler almaktadır. Katsayının işaretine göre ilişki ya pozitif ya da negatif olarak ifade edilmektedir (Altunışık, vd., 2012: 228).

Tablo 11. Kaygı ve Beklentiye İlişkin Korelasyon Analizi Bulguları

\begin{tabular}{lcccc}
\hline \multicolumn{1}{c}{ B о $\boldsymbol{y}$ u $\boldsymbol{t}$ la $\boldsymbol{r}$} & 1.Boyut & 2.Boyut & 3.Boyut & 4.Boyut \\
\hline \hline Kişisel Beklentiler & 1 & & & \\
Mesleki Beklentiler & $0.566^{* *}$ & 1 & & \\
Toplumsal Beklentiler & $0.516^{* *}$ & $0.415^{* *}$ & 1 & \\
Mesleki ve Toplumsal Kayglar & $-0.160^{* *}$ & $-0.086^{* *}$ & $-0.106^{* *}$ & 1 \\
\hline
\end{tabular}

** $p<0,01$ Düzeyinde Anlamlı Korelasyon; $0<r<0,33$ : Zaylf şiddette İlişki; 0,33<r<0,66: Orta Şiddette İlişki; 0,66/ $<r<0,99$ : Güçlü Şiddette İlişki.

Tablo 11 incelendiğinde öğrencilerin beklentilerine ilişkin ortaya çıan tüm boyutlar arasında pozitif, orta şiddette ve anlamlı bir ilişki tespit edilmiş̧ir. Ancak bu ilişkilerden özellikle "Mesleki Beklentiler" ile "Kişisel Beklentiler" boyutları arasındaki ilişki güçlüye yakındır. Mesleki beklentilerinde kişisel isteklere yakın bir beklenti olması bunu ortaya çıkaran bir sebep olarak ele alınabilir. "Mesleki ve Toplumsal Kaygılar" ile tüm beklenti boyutları arasında ise negatif ve düşük düzeyde bir ilişki tespit edilmiştir. Bireylerin geleceğe yönelik beklentileri arttıkça mesleki veya toplumsal kaygıları azalmaktadır.

\section{TARTIŞMA ve/veya SONUÇ}

$\mathrm{Bu}$ çalışmanın sonuçları Türkiye'de turizm eğitimi alan gençler ile ilgilidir. Bu çalışmanın sonuçlarına göre Türkiye'deki Üniversite öğrencilerin beklentilerini belirleyen en önemli unsur meleğin yapısıdır (fonksiyonlarıdır). Bu durum Kokt ve Strydom (2014) ile Güzel'in (2006) yaptıkları çalışmaların sonuçları ile de benzerlik göstermektedir. Bu çalışmada kaygı ve beklentiyi etkileyen en önemli demografik faktörlerin başında cinsiyet gelmektedir. Özellikle hayata ilişkin kişisel beklentiler, toplumsal beklentiler ve kişilerin hem mesleki hem de toplumsal anlamda sahip oldukları kaygılar kişilerin cinsiyetlerine göre farklılık göstermektedir. $\mathrm{Bu}$ çalışmanın sonuçları Zengin ve arkadaşlarının (2011) yaptıkları çalışmanın sonuçları ile benzerlik göstermektedir. Erkek öğrenciler daha fazla beklentiye sahipken, kız öğrencilerin kaygıları daha fazladır. Bu sonuç farklı özelliklere sahip ülkelerde farklı sonuçlar üretebilir. 
Başta insan hakları ve özgürleşme olmak üzere ülkelerin sosyal ve ekonomik gelişmişlik durumları bunda belirleyici rol oynayabilmektedir.

Üniversite öğrencilerinin yaşları arttıkça beklentileri de düşmektedir. Özellikle öğrencilerin mezun olmaya yakın olmaları ve eğitim gördükleri endüstri veya sektördeki işletmelerde staj veya yarı zamanlı olarak iş hayatına katılmaları bu sonucun ortaya çıkmasındaki önemli bir sebep olarak ifade edilebilir. Aynı şekilde öğrencilerin eğitim düzeyleri yükseldikçe beklentileri de düşmektedir. Çünkü üniversite öğrencilerinin eğitim düzeyi düştükçe, yaşları da düşmekte ve mesleki hayata ilişkin tecrübeleri de daha az olmaktadır. Tüm bunlar beklentilerin daha yüksek tutulması gibi bir durumu da beraberinde getirmektedir. Çağlar ve arkadaşları (2012) yaptıkları çalışmada eğitim durumunun özellikle sosyal kaygıları belirlemede etkin olduğu ifade etmektedir. Bu sonuçlar bu çalışmanın sonuçları ile de farklılık göstermektedir. Çünkü bu çalışmada öğrencilerin kaygılarını belirlemede eğitim durumunun belirleyici bir rolü tespit edilememiştir. Öğrencilerin okudukları üniversiteden kamu veya özel üniversite olması kaygılarını etkilemezken, toplumsal beklentilerini etkileyebilmektedir. Kamu üniversitelerinde okuyan öğrencilerin toplumsal beklentileri daha yüksek olmakta, buna karşın özel üniversitelerde daha az olmaktadır.

Öğrencilerin kişisel geliri düştükçe toplumsal beklentileri artmaktadır. Gelir durumu düşük öğrenciler genellikle sosyo-ekonomik seviyeleri düşük olan ailelerin çocuklarıdır. $\mathrm{Bu}$ nedenle az gelişmiş ve gelişmekte olan ülkelerde sosyo-ekonomik seviyeleri düşük ailelerin üniversitelerde öğrenim gören çocukların daha yüksek beklentilere sahip olabilecekleri söylenebilir. Özellikle toplumda daha iyi yerlere gelmek adına güçlü bir toplumsal beklentiye sahip oldukları söylenebilir.

Öğrencilerin gelir kaynakları da kaygı ve beklentilerini önemli ölçüde etkileyebilmektedir. Gelirlerini ailelerinden elde eden öğrenciler daha yüksek beklenti sahibi iken daha az kaygı taşımaktadırlar. Çünkü bu öğrenci grupları ekonomik ve sosyal sorumluluk almadıkları için gelecekle ilgili kaygı ve beklentileri bu duruma göre şekillenmektedir. Ayrıca öğrencilerin ailelerin yaşadıkları bölgelerin sosyal, ekonomik ve kültürel yapısı da öğrencilerin kaygı veya beklenti düzeylerini etkilemektedir. Özellikle kırsal bölgelerde, ekonomik ve sosyal yönden daha az gelişmiş coğrafyalarda ikamet eden ailelerin çocukları gelecekle ilgili daha fazla kaygı taşımaktadırlar.

Bir ülkedeki genç nüfusun geleceğe yönelik kaygı ve beklentilerini etkileyen birçok faktör olabilir. Bunlar o ülkenin ekonomik, sosyal, politik veya kültürel değerleri ile yakın ilişkilidir. Örneğin aile ve toplumsal yapı gibi sosyal ve kültürel yönü olan, ekonomik istikrarsızlık, siyaset, terör ve bürokrasi gibi politik konular öğrencilerin kaygı ve beklentilerini etkileyen konuların başında gelmektedir. Çalışmadaki bu sonuç Saw ve arkadaşlarının (2013) yaptığı çalışmanın sonuçları ile benzerlik göstermektedir. Türkiye gibi geleneklerine önem veren ülkelerde, aile yapısı veya aile baskısı kaygı ve beklentiyi belirleyen önemli bir faktör olarak ön plana çıkabilmektedir. Terör olaylarının olduğu ülkelerde terör konusu birçok toplumun bütün kesimleri olduğu gibi, gençler için kaygıya sebep olan önemli bir faktör olarak ifade edilebilir. Ayrıca ekonomik istikrarsızlık ve eğitim gibi konular da gençlerin kaygı ve beklentilerini etkilemede rol oynayabilmektedir. Bu sonuçlar, Dursun ve Aytaç (2012)'ın yaptığı çalışma ile benzer sonuçlar göstermektedir.

$\mathrm{Bu}$ araştırma sürecinde Türkiye genelinden 30 üniversiteden veri toplansa da, bütün Türkiye'ye genellenememektedir. Bu, araştırmanın en önemli kısıttı olarak ifade edilebilir. Bunun için hem maddi hem de fiziksel imkânlar oluşmamıştır. Ayrıca belirlenen bazı üniversitelerden beklenenin altında veri elde edilmiştir. Ancak bütün bu sınırlıklara rağmen bu çalışma kapsamında, konu ile ilgisi olan paydaşlara bazı öneriler getirilebilir. Öncellikle turizmle ilgili başta üniversiteler olmak üzere kamu ve özel sektör kuruluşlarının ortak hareket ederek öğrencilerin kaygı ve beklenti düzeylerin makul seviyelere getirilmesi amacıyla bazı çalışmalar 
gerçekleştirebilirler. Öncellikle başta meslek yasası olmak üzere, üniversite mezunu gençleri iş yaşamlarındaki özlük haklarını iyileştirici tedbirler alınabilir. Kamunun gençlerin kaygı ve beklentilerini etkileyen faktörlerle ilgili tedbirler almaları yararlı olabilmektedir. Örneğin aileler bu süreçte çocuklarına baskı yapmamaları konusunda eğitilebilirler. Üniversite eğitiminin daha işlevsel olabilecek bir hale gelmesi için bütün paydaşlar çalışma yürütebilirler. Bununla birlikte, Turizm fakültesi mezunu gençlerin başta turizm ile ilgili birimler olmak üzere kamu istihdamında tercih edilebilirler. Bununla birlikte, Türkiye'de üniversiteye giriş sürecinde aileler üniversite eğitimine olduğundan fazla anlamlar yüklemektedir. Bu durum öğrencilerin beklenti düzeylerinin oldukça fazla olmasını beraberinde getirmektedir. Ailelerin okul veya okul dışı danışmalık hizmeti alarak, çocuklarına üniversite eğitimi konusunda baskılar kurmanın önüne geçilmelidir. Üniversitelerinde bünyelerinde eğitme başlayan öğrencilere oryantasyon eğitimleri yoluyla makul düzeyde kaygı ve beklentiye sahip olmalarına olanak sağlamaları yaralı olabilir. Son olarak, bu konuda çalışmak isteyen yeni araştırmacılara, farklı ülkelerde araştırmalar yaparak sonuçları bu çalışmanın sonuçlarıyla karşılaştırmaları önerilebilir. Çalışma yapılacak bu ülkeler hem Türkiye'ye benzer hem de Türkiye'den farklı sosyo-ekonomik özelliklere sahip olabilirler. Bu çalışma Türkiye'nin geneli için yapılmıştır. Bazı spesifik bölge veya üniversiteler için yapılabilir. Nicel yöntemlerin yanında odak grup görüşmesi ve gözlem gibi interaktif nitel araştırma yöntemleri ile öğrencilerin kayg1 ve beklentileri irdelenebilir. Elde edilecek benzer sonuçlar politikacıların ve karara alıcıların eğitim ile ilgili politikalarına yön verebilir.

\section{KAYNAKÇA}

Altunışık, R., Coşkun, R., Bayraktaroğlu, S. \& Yıldırım, E. (2012), Sosyal Bilimlerde Araştırma Yöntemleri SPSS Uygulamall. Sakarya: Sakarya Kitapevi.

Anderson, B. A. (2006). Crisis Management in the Australian Tourism Industry: Preparedness, Personnel and Postscript. Tourism Management, 27(6): 1290-1297, DOI: 10.1016/j. tour-man.2005.06.007.

Aymankuy, Y. \& Aymankuy, Ş. (2013). Turizm İşletmeciliği Eğitimi Alan Öğrencilerin Turizm Sektöründeki İstihdamla ilgili Görüşleri ve Sektördeki Kariyer Beklentileri (Balıkesir Üniversitesi Turizm İşletmeciliği ve Otelcilik Yüksekokulu Örneği. Akademik Bakış Dergisi, (35): 1-21, ISSN:1694-528X.

Bayoğlu, A. S. \& Purutçuoğlu, E. (2010). Yetiştirme Yurdunda Kalan Ergenlerin Gelecek Beklentileri ve Sosyal Destek Algılar1. Kriz Dergisi, 18(2): 27-39

Büyüköztürk, Ş. (2005). Sosyal Bilimler Iç̧in Veri Analizi El Kitabı: İstatistik, Araştırma Deseni, SPSS Uygulamaları ve Yorum, Ankara: Pegem Akademi Yayınları

Can, A. (2014). SPSS ile Bilimsel Araştırma Sürecinde Nicel Veri Analizi, Ankara: Pegem Akademi Yayınları

Chuang, N. K., Goh, B. K., Stout, B. L. \& Dellman J. M. (2007). Hospitality Undergraduate Career Choices and Factors Influencing Ommitment to the Profession. Journal of Hospitality and Tourism Education, 19(4): 28-37, DOI: 10.1080/10963758.2007. 10696902.

Clements, M. A. \& Georgiou, A. (1998). The Impact of Political Instability on a Fragile Tourism Product. Tourism Management, 19(3): 283-288, DOI: S0261-5177(98) 00012-0.

Çağlar, M. Dinçyürek, S. \& Arsan, N. (2012). Üniversite Öğrencilerinin Sosyal Kaygılarının Belirlenmesi. Hacettepe Üniversitesi Eğitim Fakültesi Dergisi, (43): 106-116

Demir, Ş. Ş. (2013). Beklenti, Algılanan Kalite Değer ve Memnuniyet İlişkisi: Turizm Lisans Öğrencileri Üzerine Bir Uygulama. International Journal of Human Sciences, 10(1): 307-324, ISSN: 1303-5134.

Douglas, J., Douglas, A. \& Barnes, B. (2006). Measuring Student Satisfaction at a UK University. Quality Assurance in Education, 14(3): 251-267, DOI:10.1108/09684 880610678568.

Dursun S. \& Aytaç, S. (2012). Üniversite Öğrencilerinin İşgücü Piyasasına Yönelik Beklentileri ve İş Deneyimleri ile Umutsuzluk ve Kaygı Düzeyleri Arasındaki İlişki Üzerine Bir Araştırma. Celal Bayar Üniversitesi Sosyal Bilimler Dergisi, 10(1): 373-388, ISSN: 1304-4796. 
Ehtiyar, R. \& Üngüren, E. (2008). Lise ve Üniversitede Turizm Eğitimi Alan Öğrencilerin Demografik Değişkenlerinin Umutsuzluk ve Kaygı Düzeylerine Etkilerinin Araştırılması. Ticaret ve Turizm Eğitim Fakültesi Dergisi, (2): 34-51, ISSN 1301-4838.

Emanuel, R. \& Adams, J. N. (2006). Assessing College Student Perceptions of Instructor Customer Service via the Quality of Instructor Service to Students (QISS) Questionnaire. Assessment \& Evaluation in Higher Education, 31(5): 535-549, DOI: 10.1080/02602930600679548.

England, B. J., Brigati, J. R. \& Schussler, E. E. (2017). Student Anxiety in Introductory Biology Classrooms: Perceptions about Active Learning and Persistence in the Major. PLOS ONE | https://doi.org/10.1371/journal.pone.0182506, 3 August: 1-17.

Fırat, A. \& Açıkgöz, İ. (2011). Konaklama İşletmelerinin Kriz Dönemlerinde Uyguladıkları Pazarlama Stratejileri. Muğla Üniversitesi Sosyal Bilimler Enstitüsü Dergisi, (27): 1-21, ISSN 1302-7824.

Fielding, D. \& Shortland, A. (2011). How Do Tourists React to Political Violence? An Empirical Analaysis of Tourism in Egypt. Defence and Peace Economics, 22(2): 217-243, DOI: 10.1080/10242694.2011.542340.

Fitzpatric, S. J., Monda, S. J. \& Wooding, C. B. (2016). Great Expectations: Career Planning and Training Experiences of Graduate Students in Sport and Exercise Psychology. Journal Of Applied Sport Psychology, (28): 1427, DOI: $10.1080 / 10413200.2015 .1052891$

Guest, M. \& Duyen L. T. H. (2016). Student Preferences, Expectations and Anxieties Regarding an Online Exchange Program: Reports from Japan and Vietnam. 3L: The Southeast Asian Journal of English Language Studies, 22(1): 6779, ISSN 0128-5157.

Güleri, M. (1998). Üniversite ve İşçi Gençliğin Gelecek Beklentileri ve Kötümserlik-İyimserlik Düzeyleri. Kriz Dergisi, 6(1): 55-65

Güzel, N. G. (2006). Yükseköğretimde Turizm Eğitimi ve Hizmet Kalitesi, Yayınlanmamış Doktora Tezi, Ankara: Gazi Üniversitesi Eğitim Bilimleri Enstitüsü

Hall, C. M. \& O’sullivan, V. (1996). Tourism, Political Instability and Violence. İçinde A. Pizam \& Y. Mansfeld (Eds.), Tourism, Crime and International Security Issues, (pp.105-120), New Jersey: Published John Wiley

Hallgren, M. \& Wilson, T. L. (2008). The Nature And Management of Crises In Construction Projects: Projects as Practice Observations. International Journal of Project Management, 26(8): 830-838, DOI:10.1016/j.ijproman.2007.10.005.

Kokt, D. \& Strydom, A. J. (2014). Reflecting on Industry and Student Expectations for Working in The Tourism and Hospitality Industry: A Case Study South African Journal for Research in Sport. Physical Education and Recreation, 36(1): 119-130, ISBN: 0379-9069.

Malecki, C. K. \& Demaray, M. K. (2002). Measuring Perceived Social Support: Development of the Child and Adolescent Social Support Scale (CASSS). Psychology in the School, 39(1): 1-18, DOI: 10.1002/pits.10004.

McWhirter, E. H. \& McWhirter, B. T. (2008). Adolescent Future Expectations of Work, Education Family and Community. Youth \& Society. 40(2): 182-202, DOI:10.1177/ 0044118X08314257I:

Öner, N. \& Le Compte, W. A. (1983). Durumluk-Sürekli Kaygı Envanteri El Kitabı. İstanbul: Boğaziçi Üniversitesi Matbaas1.

Öztürk, Y. \& Şimşek, E. (2013). Politik İstikrarsılılıların Turistlerin Destinasyon Seçimine Etkisi Üzerine Bir Araştırma. Journal of Tourism and Gastronomy Studies, 1(2): 15-25, ISSN: 2147-8775.

Pearson, C. \& Clair, J. A. (1998). Reframing Crisis Management. Academy of Management Review, 23(1): 59-76, Stable URL: http://www.jstor.org/stable/259099.

Prior, K. \& Cox, K. A. S. (2014). Students' Expectations of Ageing: An Evaluation of the Impact of Imagined Intergenerational Contact and the Mediating Role of Ageing Anxiety. Journal of Experimental Social Psychology, (55): 99-104, https://doi.org/ 10.1016/j.jesp.2014.06.001.

Richardson, S. (2009). Undergraduate's Perceptions of Tourism and Hospitality Management. International Journal of Hospitality Management, 28(3): 382-388

Saiti, A. Papa, R. \& Brown, R. (2017). Postgraduate Students' Factors on Program Choice and Expectation, Journal of Applied Research in Higher Education, 9(3): 407-423

Saw, A., Berenbaum, H. \& Okazaki, S. (2013). Influences of Personal Standards and Perceived Parental Expectations on Worry for Asian American and White American College Students. Anxiety, Stress, \& Coping, Routledge: Taylor \& Francis, 26(2): 187-202, DOI 10.1108/JARHE-06-2016-0040. 
Scheier, M. F., Weintraub, J. K. \& Carver, C. S. (1986). Coping With Stress: Divergent Stategien of Optimist and Pessimist. Journal of Personality and Socioal Psychology, 51(6): 1257-1264, DOI: 10.1037/0022-3514.51.6.1257.

Tabachnick, B. G. \& Fidell, L. S. (2013). Using Multivariate Statistics. New Jersey: Pearson Education Inc. Publishing

Tuncer, M. (2011). Yükseköğretim Gençliğinin Gelecek Beklentileri Üzerine Bir Araştırma. Turkish Studies, 6(2): 935-948, DOI: 10.7827/TurkishStudies.2265

Tuncer, M. (2011). Ergen Gelecek Beklentileri Ölçeğinin Türkçeye Uyarlanmas1. Turkish Studies, 6(3): 1265-1275, DOI: $10.7827 /$ TurkishStudies.2335

Tutar, H. (2007). Katı Olan Her İş Sanallaşıyor veya İşgörenin Artan Yalnızlığı Üzerine: Kuramsal Bir Yaklaşım. Endüstri Iliş̧kileri ve Insan Kaynakları Dergisi, 9(2): 116-141, DOI: 10.4026/1303-2860.2007.0046.x.

Uluçay, T., Özpolat, A. R., İşgör, İ. Y. \& Taşkesen, O. (2014). Lise Öğrencilerinin Gelecek Beklentileri Üzerine Bir Araştırma. NWSA-Education Sciences, 9(2): 234-247, http://dx.doi.org/10.12739/NWSA.2014.9.2.1C0616

Üngüren, E. \& Ehtiyar, R. (2009), Türk ve Alman Öğrencilerin Umutsuzluk Düzeylerinin Karşılaştırılması ve Umutsuzluk Düzeylerini Etkileyen Faktörlerin Belirlenmesi: Turizm Eğitimi Alan Öğrenciler Üzerinde Bir Araştırma. Journal of Yaşar University, 4(1)4: 2093-2127.

Zaaba, Z., Gunggut, H., Arapa, A, \& Aning, I. N. A. (2015). Postgraduate Research Completion: Student Expectation and Inspiration, Procedia - Social and Behavioral Sciences, (202): 181-188, DOI: 10.1016/j.sbspro.2015.08.221.

Zengin, B., Şen L. M. \& Taşar O. (2011). Marmara Bölgesinde Turizm Lisans Öğrencilerinin Konaklama Sektöründe Cinsiyete Göre Kariyer Düşünceleriyle İlgili Bir Araştırma. International Conference On Eurasian Economies 2011, SESSION 3B: Turizm ve Mikroekonomi 


\section{Extended Summary}

\section{Determination of the Anxiety and Expectations of University Students About Their Future}

In this study, state and private universities in Turkey in the field of tourism education students aimed to investigate the concerns and expectations. In this context, it tried to reach multidimensional results such as what kind of anxiety and anxiety and expectations students have, what demographic features affecting anxiety and expectations, what are the factors that cause anxiety and expectations, and what is the relationship between anxiety and expectation levels. This study, which to contribute to the literature and in terms of providing guidance to decision makers in Turkey shaping the future are believed to be important.

The population of the study are students of higher tourism education in Turkey. Within the scope of the study, sampling calculation was not made and it was aimed to reach maximum participants by using appropriate sampling methods. In this context, two types of non-probability sampling types were collected from snowballing and convenience sampling methods. It was aimed to collect data from 3,000 participants by sending 100 questionnaires to 10 foundations and 20 state universities. Erroneous and incomplete surveys were eliminated from 2600 questionnaires returned and data obtained from 2,578 participants were included in the analysis. In the research, data were collected by using quantitative research techniques. Questionnaire technique was used as a data collection tool. The survey used in the research consists of three parts. In the first part, there are expressions that measure students' anxiety and expectations. In the second part, the students are given to factors which may affect their concerns and expectations in Turkey. In this last section, 7 questions were used to determine the demographic characteristics of the students. The data obtained were analyzed with the help of statistical programs.

Some methods were used to ensure the validity requirement for the questionnaire used in the study. Especially in the context of surface and scope validity, the questionnaire used in the study consists of the expressions used in many studies in the literature and the final form of the questionnaire is obtained from the experts, and it is an important reference for the validity of the study. In addition, a pilot study was conducted on 100 questionnaires collected from Sakarya University of Applied Sciences, Faculty of Tourism, and as a result of this study, it was seen that the questionnaire used in the study was able to answer the research problem. Besides, the data set obtained after completing the data collection process was evaluated separately for state and foundation universities. Alpha value for the overall reliability of the scale used in the study was determined to be 0.853 . This value indicates that the reliability requirement is met because it is over 0.70 (Altunışık, et al., 2012: 126).

There are many factors that increase the anxiety levels of students who are studying tourism, but decrease their expectation levels. Sectors such as the sector they are in demanding industrial skills, interindividual communication, customer oriented and labor intensive operation are some of them (Kokt and Strydom, 2014). Because with the influence of technology, individuals now desire to work in jobs that demand mechanical knowledge beyond a social work environment. Therefore, the anxiety levels of individuals who will work in jobs requiring social relations in the future are high and their expectations are low.

The reason for the university students to be happy in their future lives is the realization of their expectations. In fact, as reflected in the studies of Hawthorne, the source of working efficiently is the expectation levels of happiness and low anxiety levels. However, experiencing negative situations such as anxiety are expectations about the events rather than the events themselves. The most crowded group of these feelings is young people and especially university students. In particular, the concepts of expectations and concerns for tourism students in Turkey 
can be seen in a prominent manner. Because these individuals do not have employee personal rights and legal protection in their professional life after university education (Üngüren \& Ehtiyar, 2009).

Kokt and Strydom (2014) took the industrial factors into account while measuring the expectations of tourism students. In this context, they tried to measure the mutual expectations of the industry stakeholders and tourism students. The researchers' work was carried out in the Bloemfontein region of South Africa. As a result of the study, it was concluded that many students want to start their own business as it is easy to establish a small business in the region. Students who do not want to be entrepreneurs generally want to work in areas such as congress/conference and event management/organization. In addition, as a result of the study, it was obtained that if the students have high technical and management skills, the expectations regarding the future will be more positive.

Richardson (2009) emphasizes that although students have positive expectations during their education periods, their expectations regarding career opportunities in the tourism industry may be negative after their experience in business life. Chuang et al. (2007) reveal that students studying in lower grades have a narrower career expectancy range close to graduation compared to senior students. Because senior students are in a more intense relationship with the industry due to their internships and workplace practices.

According to the results of this study, that determines the expectations of university students in Turkey the most important factor is the structure of the profession (are functions). This situation is similar to the results of the studies of Kokt and Strydom (2014) and Güzel (2006). In this study, gender is one of the most important demographic factors that affect anxiety and expectation. Especially personal expectations, social expectations and concerns of people both professionally and socially differ according to their gender. The results of this study are similar to those of Zengin et al. (2011). While male students have more expectations, female students are more concerned. This result may produce different results in countries with different characteristics. Human rights and emancipation, social and economic development can play a decisive role in the emergence of this difference. In addition, age, education level, type of university, income status, geographic regions where the residents reside stand out as demographic variables that affect students' anxiety and expectations.

There may be many factors that affect the future anxiety and expectations of the young population in a country. These are closely related to the economic, social, political or cultural values of that country. For example, political issues such as family and social structure that have social and cultural aspects, such as economic instability, politics, terrorism and bureaucracy are among the issues that affect students' anxiety and expectations. This result in the study is similar to the results of the study done by Saw et al. (2013). In traditional countries such as Turkey, family structure or family pressure can come to the fore as an important factor in determining expectations and anxiety. In countries where there are terrorist incidents, the issue of terrorism can be expressed as an important factor that causes anxiety for young people, as in all segments of many societies. In addition, issues such as economic instability and education can play a role in influencing youth's anxiety and expectations. These results show similar results with the study of Dursun and Aytaç (2012). 
Optimum Journal of Economics and Management Sciences, Vo1. 7, No. 2- http://dergipark.org.tr/optimum Zengin and Şengel - Determination of the Anxiety and Expectations of University Students about Their Future 